\title{
ENGLISH AND INDONESIAN GREETINGS AS ADJACENCY PAIRS: A PRAGMATIC STUDY
}

\author{
Arni Arsyad Sultan \\ STIKES Nusantara Jaya Makassar \\ arnisultan@gmail.com
}

\begin{abstract}
A speaker customarily opens the conversation by saying greeting to his or her interlocutor. At a glance, greetings maybe not a complicated activity but for the most part, they are highly conventionalized and follow patterned routines. Despite it, the pattern or sequence of greetings along with its type is dynamic and developed. The research aimed to describe the kinds of verbal and nonverbal greetings customarily shown in every exchange, to reveal the sequence of English and Indonesian greetings as adjacency pairs in social exchange. The data consists of English collected from "Twelve Years a Slave" while Indonesian data are obtained from observation, record, and field notes. Both of the data are analyzed by using descriptive qualitative method. The result of this research indicates that there are four types of Indonesian sequential greetings uncovered by Firth's theory, characterized by interjection-question, question-body language, interjection-invitation, and invitation. Each is used in a single utterance for each pair. Second, English data indicate the sequences of greetings uttered by first pair and second are symmetrical, body language preceding question, and body language, on the other hand, Indonesian greeting sequence, the researcher finds an asymmetrical pattern, question preceding question, body language, and visual response. Miscellaneous greeting sequences also appeared in both such as affirmation and facial expression, question and affirmation, affirmation and invitation, invitation and affirmation, and also question and direct answer.
\end{abstract}

Keywords: types of greetings, adjacent pair of greetings

\begin{abstract}
ABSTRAK
Seorang pembicara biasanya membuka percakapan dengan mengucapkan salam kepada lawan bicaranya. Sepintas, salam mungkin bukan tindakan yang rumit, tetapi sebagian besar salam itu konvensional dan mengikuti rutinitas yang terpola. Meskipun demikian, pola atau urutan salam beserta jenisnya itu dinamis dan berkembang. Tujuan dari penelitian ini adalah untuk menggambarkan jenisjenis ucapan verbal dan non verbal yang biasanya ditampilkan dalam setiap interaksi, untuk mengungkapkan urutan ucapan bahasa Inggris dan bahasa Indonesia sebagai pasangan adjacency dalam sosial. Data terdiri dari bahasa Inggris yang dikumpulkan dari "Twelve Years a Slave" sementara data Indonesia diperoleh dari observasi dan catatan lapangan. Kedua data dianalisis dengan menggunakan metode deskriptif kualitatif. Hasil penelitian ini menunjukkan bahwa ada empat jenis salam dalam urutan Indonesia yang ditemukan berasarkan teori Firth, dicirikan dengan kata serupertanyaan, pertanyaan-bahasa tubuh, kata seru-undangan, dan undangan. Masing-masing digunakan dalam ucapan tunggal untuk setiap pasangan. Kedua, data bahasa Inggris menunjukkan urutan salam yang diucapkan oleh pasangan pertama dan kedua adalah simetris, bahasa tubuh sebelum pertanyaan, dan bahasa tubuh, di sisi lain, urutan ucapan Indonesia, peneliti menemukan pola asimetris, pertanyaan sebelumnya, bahasa tubuh, dan respon visual. Urutan ucapan lainnya juga muncul dalam afirmasi dan ekspresi wajah, pertanyaan dan afirmasi, afirmasi dan undangan, undangan dan afirmasi, dan juga pertanyaan dan jawaban langsung.
\end{abstract}

Kata kunci: jenis salam, pasangan salam yang berdekatan 


\section{INTRODUCTION}

The conversation starts with greetings and then it moves to the topic until it ends with closings. At a glance, the speaker may feel that greetings are not a complicated act. However, the type and structure of greetings can vary from culture to culture. (Kirdasi, 2013) attempts to describe and compare the use of "hello" used by Americans on Ramadhan and "salaam" used by Arabians on Christmas and Thanksgiving. The different modes of greetings from global perspectives around the world are also discussed by paying attention to the situational background of greeting (Ahmad, 2015). Forms of greetings between two cultures can also be different. (Meiirbekov et al. 2015) report that there are some peculiarities and similarities of greeting forms between English and Kazakh in expressing and exchanging greetings related to various situations. Types of Buginese greetings such as closed intimacy, joking, exclamation, and body appearance are reported to be more varied than in English types namely time-bound, phatic, and exclamation (Inayah, 2015).

The role of a certain contextual situation when people greet each other presents and affect the interaction between the speakers. (Negargar, 2015) reports that there are such significant differences existed in a way that speech acts of greeting are realized in terms of structure, formality, and frequency. (Sithebe, 2011) reveals that there are marked differences in which American English speakers and Swazi people perform and interpret greeting and request. Similarly, the speech act of greeting and apology are investigated to display their effects among Jordanian society (Laila, 2013).

The differentiation based on gender in delivering greeting is also taken into consideration. The research on how the speaker's gender affects greeting has been done by (Dezhara et al.,2012). He discovers that the great differences in the verbalize behavior associated with the speaker's sex affect the use of greetings among male and female speakers of Persian. (Junaid, 1999) finds that greeting and leave-taking can be divided into some proper patterns based on the status and gender of the speakers.

This research attempts to show and explain that the types of greeting are more widely varied and it is different from prior research since contexts take place in the conversation. Moreover, sequential patterns of greeting may vary depending on the various dynamic situations. This research is conducted to describe the surface structure or the order of greetings when speakers turn to talk at the very beginning of their conversation by using a pragmatic approach.

\section{LITERATURE REVIEW}

Society and language are two elements that cannot be separated from each other. What language uses in society is the discussion of pragmatics. Pragmatics is the study of language use, syntax as the configuration of words and their parts, and semantics is the study of meaning (Levinson, 1983). (Hatch, 1992) stated that 
pragmatic meaning is that a meaning which comes from the context rather than from syntax and semantics. For example a sentence "I didn't see you" could have a pragmatic meaning of an excuse or apology. (Fasold, 1990) defines pragmatics as the study of the use of context to make inferences about meaning. Context is defined by (Leech 1989 in Waskita, 2014) as equal knowledge of speech owned by speaker and hearer and it helps the hearer to interpret the meaning of utterances. Context is related to the situational and cultural background of participants to understand the messages.

\section{Adjacency Pairs}

APs are the fundamental units and they are operated in conversation to manage the sequence of speakers in producing utterance. (Levinson, 1983) adjacency pairs are kind of paired utterances which relate to turning taking techniques for selecting the next speaker, especially where an address term is included or the content of the first utterance isolates a relevant next speaker. (McCarthy, 1991), APs are often mutually dependent. The examples are that a question predicts an answer and an answer presupposes a question. Some instances can be seen as follows:

$\begin{array}{ll}\text { Utterance function: } & \text { Expected responses: } \\ \text { Greeting } & \text { Greeting } \\ \text { Congratulation } & \text { Thank } \\ \text { Apology } & \text { Acceptance } \\ \text { Inform } & \text { Acknowledge } \\ \text { Leave-taking } & \text { Leave-taking }\end{array}$

Some APs are usually ritualized utterances. When the first pair-part says "hello" or "happy new year", the speaker has an identical response from second pair-part "hello", "happy new year". The response from the second pair can be expected more or less the same. as follows:

(Schegloff and Sacks, 1973 in Levinson, 1983) created characterization of AP

(1) Adjacent

(2) Produced by different speakers

(3) Ordered as the first part and a second part

(4) Typed, so that a particular first part requires a particular second.

\section{Turn-Taking Mechanism}

The turn-taking mechanism is the distribution of talk across two participants (Levinson, 1983). The first speaker should allow the next speaker to talk. When this happens, the current speaker stops talking and the next speaker starts producing utterance. The notion of this is A talks, stops, and B starts, talks, stops. Then A-B-AB-A-B is obtained (Levinson: 1983: 296).

\section{The Definitions of Greeting}

There are many waves of definition for greeting among linguists and scholars 
based on their researches. (Fieg and Mortlock, 1989 in William, 1997) from a crosscultural viewpoint stated that greetings are defined as "ritualistic expression" carrying some types of pragmatic meaning. On their study to Americans and Thais in three different situations; work, passing on the street, and personal encounters, Americans are reported to say "what's happening?" or "what's new" when passing on the street. (Fieg and Mortlock, 1989 in William, 1997), these greetings should affect the listener causing non-formulaic responses about events. (Firth, 1972 in Youssouf, 2009) characterizes greetings as the recognition of an encounter with another person as socially acceptable. Encounters can be divided into three sorts (Youssouf, 2009: 800), those are familiars, those are we know of but whom we have not met, and those are strangers. Greetings are also "access rituals" consisted of passing greetings and engaging greetings (Goffman in Williams, 1997). Greetings are arranged by some interlinking behaviors; salutation, the term of address, body language, and social context. (Nodoushan, 2006 in Jibreen, 2010), greetings have two important features. First, they occur at the very beginning of a conversation and cannot be alone elsewhere in the conversation. Second, they allow all the speakers a turn, right at the beginning of a conversation. Meanwhile, according to (Austin, 1962), Greeting is considered as a kind of performative concerning behavior towards others to exhibit attitudes and feelings (Jibreen, 2010).

Criteria for Identifying Greetings across Languages

There are six features to identify greetings in a social community across languages shown in the following criteria (Duranti, 1997):

a) Near boundary occurrence: Greetings have identical functions as attentiongetting devices and also have abilities to establish a shared field of interaction.

b) Establishment of a shared perceptual field: Greetings may appear after a signal of recognition for someone's presence in the social encounter. Visual recognition may appear first from each or both of the speakers and then it is followed by verbal recognition. (Bach and Harnish, 1979 in Duranti, 1997) supported this criterion by classifying greetings as acknowledgments. Greeting plays as a response to finding someone's by visual sight or auditory range.

c) Adjacency pair format: AP format allows exchanges between participants in which first part (A) invites and expects reply or response from the second part (B).

d) Relative predictability of form and content: When people say "hi", or "good morning", or "how are you", participants do not merely want to access information about their interlocutors, but in their greetings, the properties of context can be identified for example the relationship between interlocutors.

e) Implicit establishment of a Spatio-temporal unit of interaction: Greetings can be analyzed into a larger unit of analysis such as a day at work, different parts of the day with family members, or interactions over months. When two people meet in two different places on the same day, they can exchange 
greetings again. An empirical investigation shows that a group of people who repeatedly come into contact throughout a day exchange greetings. This study shows that people conceptualize the different space-time zones with greetings.

f) Identification of the interlocutor as a distinct being worth recognizing: Greetings are usually carried out with typically identifying particular personal identification of interlocutors. Greetings may be accompanied by address terms or signs that can identify participants as a part of a particular social group. The use of greetings can differentiate insider or outsider, friend or foe, valuable or non-valuable interactants, etc for example in many societies, children and servants are not greeted.

\section{Types of Greetings}

Greetings can be discussed broadly in two large categories. They are timebound or free time-bound. (Halliday, 1979 in Jibreen, 2010) classified verbal greetings into time free greetings and time-bound greetings. The greetings ruled by time can be composed as "good (morning", "good afternoon", "good evening", and "good night". The demarcation of time could also base on the larger scale of the temporal unit or annual event such as "happy new year", "happy anniversary", "happy birthday", etc. in contrast, people may also interact to exchange greetings in expressing their attitude or behavior to the interlocutor by requesting or interjecting. In this case, time consideration is no longer employed for example "how do you do?", "How are you?", "hi", "hello", "glad to meet you", "nice to see you", etc.

Regarding the use of greetings tied by time, the Indonesian language also has a standard of definition governing time restrictions of greetings. Indonesian dictionary in (Rahayu, 2010), the demarcations of time are explained as follows:

a) Morning: Morning is defined as a time when a day starts or it is time after the sun rises until it is closed to noon.

b) Daylight: The obvious matter to decide this time can be understood by using a clock. Daylight refers to the time when it is $11.00-14.00$. it is clearly after morning when the sun has already risen (if the weather or season is not rainy) and before the afternoon.

c) Afternoon: Kamus Besar Bahasa Indonesia (KBBI) refers to the afternoon when it is around 15.00 until the sunsets. This time has occurred after the daylight.

d) Night: It occurs after the sun sets until the sun rises.

This demarcation of time influencing greetings adjusts with the geographical location and meteorological situation where time-bound greetings are uttered. (Rahayu, 2010), in the countries near the pole especially Holland, on a particular range of months, the sun is still visible at 21.00. However, people still employ "good evening or good night" because their assumption is based on clock or time reference.

(Krivonos and Knapp, 1975 in Jibreen, 2010) found that most common verbal greetings were topic initiation, verbal salute, and references to the interlocutor. 
(Krivonos and Knapp, 1975 in DeVito, 1999) provide some examples of these verbal greetings for example topic initiation can be the reason why the speaker wants to communicate ("the reason I called ...."), verbal salute such as "hi", "hello", etc, references to the interlocutor (hey! You're looking good), and personal inquiries ("what's new?"). Non-verbal linguistic forms composing greetings is body movement (Firth 1972). The human body is a social-instrumental greeting. It has such symbolic meaning as showing respect, humility, recognition of superior status, etc. For instance, a manager of a firm may not arise in saying good morning to his secretary.

The notions of sequencing and serial moves are central to AP and are used to explain the dynamic characteristics of verbal interaction (Jibreen 2010: 8). (Schegloff and Sacks, 1973 in Jibreen 20108) view greetings as a speech event composed of two parts side by side, serial, and sequential such as 'Greeting-Greeting', e.g.:
A: Hello
B: $\mathrm{Hi}$
Or

A: Good morning

B: Hello

The second type is 'Greeting-Request' for information. This typically occurs where the function of the second pair is replaced by another function, e.g.:

A: Hello.

B: Did you just get home?

The third type is the non-verbal greetings. It concerns with body language (William in Jibreen 2010: 7).

\section{RESEARCH METHOD}

The researcher applied the qualitative descriptive method to analyze the data since the primary data got from library and field research. Descriptive qualitative research is done to obtain an accurate profile of the people, events, or situations so it guides the researcher to explore the data in comprehensive, extensive, and deep ways (Sugiyono, 2010). This kind of analysis was used to explain explicitly the greetings based on the sequence and composition of verbal and non-verbal elements of greetings. The researcher used descriptive observation in collecting data. The descriptive observation was done whenever we looked at the social situation and tried to record the utterances in that social situation as much as possible. The researcher recorded and took notes of the data and also acted as a participant-observer who observed and participated in social activities (Spradley, 1980).

\section{FINDING AND DISCUSSION}

The English greetings were taken from the English movie "Twelve Years a Slave". The researcher took 10 utterances of greetings in the movie as the data from 
every social interaction. On the other side, in gathering Indonesian data, the researcher conducted participant observation in her neighborhood. The field research took place at Jalan Perintis Kemerdekaan 18, Tamalanrea, Makassar. There were 10 utterances of greetings as a sample of observation for Indonesian greetings.

\section{The Kinds of English Greetings}

Question:

○ Well Boy, how do you feel now?

- You're miserable one, where do you get?

Platt? Where's the boy called Platt?

Interjection

○ Wooo....!

Affirmation

- Good day, Mr. Northup.

- Mr. Northup! I have two gentlemen whom you should meet, Mr. Brown and Hamilton.

- Good day, Sir.

- Platt Epps, good Sunday morning.

$\circ$ It is very good to meet you, Sir.

Body movement

- Extending handshake.

The data displayed that each type of greeting was applied in every single utterance. In these data, it can be seen that the types of greetings consist of verbal behaviors which are question, interjection, affirmation, and nonverbal behavior which is body movement. Verbal greetings can also be divided into two types according to time demarcation. (Baidoo and Koranteng, 2008), time restriction of "good day" and "good morning" is arranged in the Standard English temporal greetings as tabulated in this following set:

\begin{tabular}{|l|l|}
\hline \multicolumn{1}{|c|}{ Time } & \multicolumn{1}{c|}{ Greeting } \\
\hline Morning & Good morning \\
\hline Mid-morning to early afternoon & Good day \\
\hline Afternoon & Good afternoon \\
\hline Evening & Good evening \\
\hline
\end{tabular}

Another point of view besides verbalizes behaviors of greeting is a nonverbal pattern. The body movement becomes the center of the non-verbal type of greeting when two speakers encounter and conduct a conversation. Physical body movements are employed to show the speaker's intention (Firth, 1972: 18). One mode of body movement can express respect, humility, and recognition of higher status. Sinking to the ground conveys a depreciation of the self. One example of body language is handshaking. In this step of greeting, the standpoint in which both of the speakers stay becomes minimal. The spatial range of distance from the first speaker to the 
second speaker is nearer to reach this step. Two people should be in near position each other when they handshake until handclasp (Yammiyavar et al, 2008).

In comparing the English data, the types of greetings of Indonesian data are shown. There are some particular extents in which the types of greeting in a social and informal exchange do not exist in English data. To sum up, here is the summary of the whole Indonesian data carried out in everyday social interaction among neighbors.

\section{The Kinds of Indonesian Greetings}

Question

- Ada mi ini? (menunjuk ke arah perut)

Are you pregnant? (pointing at stomach)

Interjection

○ Hei, dirimu.

$\mathrm{Hi}$, you.

Affirmation

- Barusang ko seng kulia' eh. Long time no see you, eh.

- Saya kira siapa.

I guess who (you are).

- Pagi.

(Good) morning.

- Assalamualaikum, kak.

Assalamualaikum, sister. (Islamic greeting)

Interjection and Question

- Hei, urus apa?

$\mathrm{Hi}$, what are you going to do?

- Oe! tante, bagaimana kabar? Sehat-sehat?

Hi! Aunty, how are you? Are you alright?

Interjection and Invitation

○ Oe! Pak, Singgahki.

Hi! Sir, come by please.

Invitation

- Masukki.

Come in, please.

The data show that Indonesian greetings also follow the theory of greeting. It can be seen from the types of sentences delivering greetings which are question, interjection, and affirmation. These types of greetings are same with the types of English greetings. However, there is another type of greeting appeared which implies invitation. This type of greeting implying invitation is an activity to maintain social relationship. It was a customary behavior in everyday life not only to communicate but also to show hospitality to other people such as neighbors or someone whom the speaker knows of when they are passing by in front of the speaker's house. The 
speaker usually offers his or her interlocutor to come by to his or her house.

\section{The Sequences of Greetings as Adjacency Pairs}

\section{English Data}

Symmetrical Pattern

○ A: Good day, Mr. Northup.

B: Good day.

○ A: Good day, Sir.

B: Good day.

- A: Platt Epps, good Sunday morning.

B: Good morning, Mr. Shaw.

Question - Affirmation

$\circ$ A: Well Boy, how do you feel now?

B: My name, my name is Solomon Northup. I am a free man. A resident of Saratoga, New York.

- A: You're miserable one, where do you get?

B: I've been nowhere.

Affirmation - Facial Expression

- A: Mr. Northup! I have two gentlemen whom you should meet, Mr. Brown and Hamilton.

B: (Smile).

Body language - Affirmation and Question

- A: (Extend handshaking).

B: It's splendid to see you. What kind of your fancy? (welcome handshake)

Interjection - Facial Expression

○ A: Wooo....!

B: (Stare at Mr. Epps).

Question - Body language

A: Platt? Where's the boy called Platt?

B: (turn around and raise hand).

Affirmation - Affirmation

○ A: It is very good to meet you, Sir.

B: We are going so much to do.

\section{Indonesian Data}

Invitation - Affirmation

○ A: Masuk ki.

Come in, please.

B: Assalamualaikum.

(Islamic greeting).

Affirmation - Affirmation

- A: Barusang ko seng kulia' eh.

Long time no see you, eh. 
○ B: Iye', aji.

Yes, mam.

Affirmation - Invitation

- A: Saya kira siapa.

I think who (you are).

B: Sarapan dulu bu.

Let's have a breakfast, mam.

Invitation - Affirmation

○ A: Oe, Pak! Singgahki.

Hi, Sir! Come by, please.

B: Iye, mari ki.

Okay, bye.

Question - Affirmation

○ A: Hei, urus apa?

$\mathrm{Hi}$, what are you going to do?

B: Mau kesana dulu.

I want to go there first.

Question - Question

- A: Oe, tante. Bagaimana kabar? Sehat-sehat?

Hi, aunty. How are you? Are you alright?

$\mathrm{B}:$ Oe, kapan datang?

$\mathrm{Hi}$, when did you come?

Question - Answer

○ A: Adami ini? (menunjuk ke arah perut)

Are you pregnant? (pointing at stomach)

B: Belum.

Not yet.

Interjection - Affirmation

○ A: Hei, dirimu.

$\mathrm{Hi}$, you.

B: Assalamualaikum.

(Islamic greeting).

Asymmetrical Pattern

- A: Pagi.

(Good) morning.

B: Joggiing dulu.

Jogging's first.

Affirmation - Facial Expression

- A: Assalamualaikum, kak.

(Islamic greeting).

B: (Stare at the first speaker)

There are some basic distinctive points of greeting sequences between English and Indonesian. Relating to the data found in this research, in exchanging greetings, 
most English data follow the typical patterns of greeting proposed in theory whereas, in Indonesian greetings, there are some modifications associated with the actual contexts when utterances are engaged between parties. Those can be seen from the sequences such as invitation - affirmation, affirmation - invitation, question question, and asymmetrical patterns.

The feature of invitation in this situation describes the positive attitude of the speaker to other people. The speaker offers good or service when they are enjoying food or when they are just sitting in front of his or her house when other people pass by. This implies that greeting is not only a matter of ritualistic routine done when people encounter their interlocutors. This phenomenon is supported by (Malinowski,1923 in Jibreen 2010) that a more important function of greeting is its social function which is to establish and to maintain social bound among members of society.

Question - question and asymmetrical pattern are other two different sequences found in this research. Question from the first speaker is responded with question by the second speaker. This describes also that people are free to communicate. It is more important to get information and to convey inquiry about the interlocutor's state of health, arrival, etc. On the other side, asymmetrical patterns in exchanging greetings happen. (Biber et al.,1999 in Jibreen 2010) label the reciprocated greeting from the first speaker as symmetrical exchange. This is in line with (Williams, 1997) who names the exact duplicate greeting as mirror greeting. However, in this research, data show that the time-bound greeting can be replied with time free greeting.

\section{CONCLUSION}

Both types and sequences of greeting from English and Indonesian have different characteristics. Each has its function utilized by the members of society to interact in everyday life. People can greet to show hospitality, to maintain a social boundary, to exchange personal information, or just to chit chat. Besides, data from English greetings match with the theories of type and sequence while there are some modifications of Indonesian greetings in type and sequence. The type of greeting is characterized by invitation and the modifications of greeting sequences are realized with invitation - affirmation, affirmation - invitation, asymmetrical pattern, and question - question.

\section{BIBLIOGRAPHY}

Ahmad, Nehal. (2015). A Study of Modes of Greetings in a Global Perspective with Particular Reference to Urdu Speech Community in India. [online] 47-122. Retrieved on November $11^{\text {th }}, 2015$. Available from: http://www.mjal.org/journal/new/4.pdf 
Ajayi, Temitope M., and Kudrat O. Balogun. 2014. Politeness in Yoruba and French Languages. International Journal of Language Studies, 8(4): 77-94.

Anderson, Katie. (2010). Film as a reflection of society: Interracial marriage and Stanley Kramer's Guess Who's Coming to Dinner in late1960s America. Journal of SURG [online], Vol. 4 (1). Retrieved on April 30 ${ }^{\text {th }}, 2016$.

Available from: https://journal.lib.uoguelph.ca

Baidoo, Yaw S., and Louisa A. Koranteng. (2008). English General Greetings in the Ghanaian Sociolinguistic Context. The International Journal of Language, Society, and Culture. 26: 113-126.

DeVito, Joseph A. (1999). Essentials of human communication [online], New York: Longman. Retrieved on April $29^{\text {th }}$, 2016. Available from: https://books.google.co.id

Dezhara, Salman., et al. (2012). A Comparative Study of Greeting Forms Common among Native Male and Female Speakers of Persian. Journal of Language Teaching and Research. 3 (6), 1224-1232.

Duranti, Alessandro. (1997). Universal and Culture-Specific Properties of Greetings [online], 63-97, retrieved on October $14^{\text {th }}, 2015$. Available from: http://www.sscnet.ucla.edu/anthro/faculty/duranti/reprints/greetings.pdf.

Fasold, Ralph W. (1990). The Sociolinguistics of Language. Cambridge: Basil Blackwell.

Firth, R. (1972). Verbal and Bodily Rituals of Greeting and Parting [A]. La Fontaine J. S. The Interaction of Ritual $\quad[C], 1-38$.

Hatch, Evelyn. (1992). Discourse and Language Education. Cambridge: Cambridge University Press.

Inayah, Nurul. (2015). Power Construction in English and Buginese Greetings. Makassar: Hasanuddin University.

Jibreen, Maysa'akadhim. (2010). The Speech Act of Greeting: A Theoretical Reading. Humans. 8 (1), 1-25.

Junaid, Asnidar. (1999). Greetings and Leave Taking in English and in Bahasa Indonesia. Makassar: Hasanuddin University.

Kirdasi, Malak Ismail. (2013). Hello or Salaam? Greetings by Arabs and Americans: a thesis. Unpublished: National Chiao Tung University.

Knapp, Mark L. (1980). Essentials of Nonverbal Communication. California: Holt, Rinehart, and Winston.

Knapp, Mark L., and Judith A. Hall. (2010). Nonverbal Communication in Human Interaction, seventh edition. Wadsworth: Cengage Learning. 
Laila, Emad M. Ahmad Abu. (2013). A Sociolinguistic Study of Greetings and Apologies used by Yarmouk and Zarqa University Students: a thesis. Unpublished: Yarmouk University.

Levinson, Stephen C. (1983). Pragmatics. Cambridge: Cambridge University Press.

McCarthy, Michael. (1991). Discourse Analysis for Language Teachers. Cambridge: Cambridge University Press.

Meiirbekov, Assylbek K., et al. (2015). Sociolinguistic Aspects of the Speech Act of Greeting in the Kazakh and English Languages. Mediterranean Journal of Social Sciences. 6 (6), 267-274.

Negargar. Sarvin. (2015). A Contrastive Study of Speech Acts of Greeting in Two Persian and English Soap Operas with Regard to the Level of Formality, Structure, and Frequency. Impact Journals. 3 (6), 47-60.

Rahayu, Ratih. (2010). Rubrik Bahasa [online]. Retrieved on July 20 ${ }^{\text {th }}, 2016$. Available from: https://rubrikbahasa.wordpress.com/2010/02/24/pagi-siangsore-dan-malam/

Schegloff, Emanuel A., and Harvey Sacks. (1973). Opening up Closings [online], 6869. Retrieved on October $14^{\text {th }}$, 2015. Available from: http://web.stanford.edu/ eckert/PDF/schegloffOpeningUpClosings.pdf

Sithebe, Faith Bonsile. (2011). The Speech Act Realization of Request and Greetings by Non-native and Native Speakers of Siswati. A Thesis. Published: University of Stellenbosch.

Spradley, James P. (1980). Participant Observation. New Jersey: Holt Rinehart and Winston.

Sugiyono. (2010). Metode Penelitian Kuantitatif, Kualitatif, dan R\&D. Bandung: Penerbit Alfabeta.

Wei, Li. (2010). The Functions and Use of Greetings. Canadian Social Science. 6 (4), 56-62.

Williams, K. (1997). An Evaluation of Greeting Exchanges in Textbooks and Real Life Settings. Modern Language Journal.

Yammiyavar, P., et al. (2008). Influence of Cultural Background on Nonverbal Communication in a Usability Testing Situation. International Journal of Design. 2 (2), 31-40.

Youssouf, Ibrahim A., et al. (2009). Greetings in the Desert. Blackwell Publishing. 